\title{
Removing Humic Acid from Aqueous Solution Using Titanium Dioxide: A Review
}

\author{
Trinh Xuan Tung ${ }^{1-3}$, Dong $\mathrm{Xu}^{2 *}$, Yi Zhang ${ }^{2}$, Qiaohong Zhou ${ }^{2}$, Zhenbin $\mathrm{Wu}^{1,2 * *}$ \\ ${ }^{1}$ School of Resources and Environmental Engineering, Wuhan University of Technology, Wuhan, P.R. China \\ ${ }^{2}$ State Key Laboratory of Freshwater Ecology and Biotechnology, Institute of Hydrobiology, \\ Chinese Academy of Sciences, Wuhan, P.R. China \\ ${ }^{3}$ Vietnam Maritime University, Haiphong, Vietnam
}

Received: 14 November 2017

Accepted: 10 February 2018

\begin{abstract}
Recently, the photocatalytic degradation technique with titanium dioxide $\left(\mathrm{TiO}_{2}\right)$ has been widely applied for the degradation of humic acid (HA) from aqueous solution due to its ability to achieve complete mineralization of organic contaminants. Because $\mathrm{TiO}_{2}$ is the most commonly used semiconductor photocatalyst, efforts on the modification of $\mathrm{TiO}_{2}$ in order to improve catalyst efficiency were presented in this review manuscript. The key photoreactor operation parameters such as $\mathrm{TiO}_{2}$ loading, $\mathrm{pH}$, temperature, oxygen concentration, concentration and nature of HA, light wavelength, light intensity, the presence of inorganic ions and mechanistic pathway for pollutant removal, and the formation of the intermediates and their effects on the mineralization and disinfection of the photo-process were also assessed. Although we can see an increase in the number of papers that have been published in this area, further progress is needed to improve the understanding of the dynamic interactions between $\mathrm{TiO}_{2}$ photocatalytic oxidation process and $\mathrm{HA}$, as well as to suggest possible future developments in this promising field.
\end{abstract}

Keywords: adsorption, aqueous solution, photocatalytic (PC), humic acid (HA), titanium dioxide ( $\left.\mathrm{TiO}_{2}\right)$

\section{Introduction}

Natural organic matter (NOM) is defined as a complex matrix of organic materials present in all surface, ground, and soil waters [1]. The presence of NOM, mainly humic substances (HS) in surface waters, constitutes the main route for the absorbance of solar energy in aquatic systems through which a series of photophysical and photochemical processes occur. Humic acid (HA) accounts for a significant fraction of the HS.

*e-mail: wuzb@ihb.ac.cn,

**e-mail: xudong@ihb.ac.cn
The presence of HA in aqueous solutions is not directly toxic but could lead to organic disinfectant by-products (DBPs), which are undesired and hazardous products in water treatment after disinfection [2-3]. Furthermore, the high HA concentration in drinking water has the potential for some serious diseases, such as stomach cancer [4-5]. Thus, the presence of HA can be the cause of many problems, and their removal from water is a priority task [6] and has been attempted in different ways. Several processes have been attempted to remove HA from water such as coagulation [7-9], electrocoagulation (EC) $[4,10-15]$, electro-oxidation (EO) [16], ion exchange [17], membrane filtration [18-20], activated carbon adsorption and advanced oxidation processes [21-29]. 
Other approaches including ozonation $\left(\mathrm{O}_{3}, \mathrm{O}_{3} / \mathrm{H}_{2} \mathrm{O}_{2}\right)$ [30-32] and gamma radiation/H2O2 [33-35], and/or UV-photolysis [36, 37] have also been widely attempted to eliminate HA from wastewater. However, the application of the proposed methods is associated with a number of disadvantages. Generally speaking, the removal of HA by conventional and advanced treatment processes is not always adequate with regards to removal efficiency, chemical, and energy consumption, and management of residuals.

Among these treatment processes, heterogeneous photocatalysis employing semiconductor catalysts has a widely demonstrated efficiency for removing or degrading HA. Compared with other photocatalysts, titanium dioxide $\left(\mathrm{TiO}_{2}\right)$ is much more promising and most commonly used [36-37] as it is stable, noncorrosive, environmentally friendly, abundant, and costeffective [5]. Owing to its application for the complete mineralization of undesirable organic contaminants to $\mathrm{CO}_{2}, \mathrm{H}_{2} \mathrm{O}$, and inorganic constituents [38-41], $\mathrm{TiO}_{2}-$ based photocatalyst materials have been found to efficiently decompose and remove a variety of pollutants: bisphenol A [42], natural organic matter [43], persistent pharmaceutical compounds [44], phenol [45], o-cresol [46], etc. Taking advantage of this inherent ability of $\mathrm{TiO}_{2}$, the degradation processes of HA involving $\mathrm{TiO}_{2}$ samples has become an important topic of research in recent years.

This review considers recent developments in the research and application of adsorption and photocatalyst $\mathrm{TiO}_{2}$ for HA removal from aqueous solution. During this work, the effects of photoreactor operating parameters on the photocatalytic process are listed in addition to mineralization and disinfection kinetics associated with their modelings.

\section{Mechanism and Limitations}

\section{Mechanism}

It has been agreed that the basic process of photocatalytic reactions are initiated by the absorption of illumination with energy equal to or greater than the band gap of the $\mathrm{TiO}_{2}$ semiconductor surface, usually $3.2 \mathrm{eV}$ (anatase) or $3.0 \mathrm{eV}$ (rutile), creating an hole in the valence band. The light wavelength for such photon energy usually corresponds to $\lambda<400 \mathrm{~nm}$.

The simplified mechanism:

$$
\mathrm{TiO}_{2}+h v \rightarrow e_{C B}^{-}+h_{V B}^{+}
$$

...where $\mathrm{CB}$ is the conduction band and $\mathrm{VB}$ is the valence band. Thus, upon UV irradiation, the electron-hole pairs $\left(e_{C B}^{-} / h_{V B}^{+}\right)$are generated by the $\mathrm{TiO}_{2}$ particle. The electron and hole can recombine and emancipate the absorbed light energy with no chemical reactions occurring. On the other hand, due to the VB hole strongly oxidizing while the $\mathrm{CB}$ electron is strongly reducing, the redox reactions can occur between them and the adsorbed species. The mineralization of HA on the surface of $\mathrm{TiO}_{2}$ is occurring by the participation between excited electron and the hole in redox reactions with water, hydroxide radical $(\mathrm{OH})$ organic compounds, or oxygen. Therefore, the $(\mathrm{OH})$ radical can be formed by both of two reactions of the valence band holes with adsorbed $\mathrm{H}_{2} \mathrm{O}$ or with the surface groups on the $\mathrm{TiO}_{2}$ particle. The reactive ( $\mathrm{OH}$ ) radical can hydroxylate the aromatic compounds, leading to a successive oxidation/addition and ring opening. The resulting intermediates will be further carboxylated to produce innocuous carbon dioxide $\left(\mathrm{CO}_{2}\right)$ and water $\left(\mathrm{H}_{2} \mathrm{O}\right)$. The overall photocatalysis reaction of $\mathrm{HA}$ to generate intermediates that ultimately lead to $\mathrm{CO}_{2}$ and $\mathrm{H}_{2} \mathrm{O}$ are depicted in the following equations:

$e^{-}$rB reactions:

$$
\begin{gathered}
\mathrm{O}_{2}+e_{C B}^{-} \rightarrow \mathrm{O}_{2}^{-} \\
\mathrm{O}_{2}^{-}+\mathrm{H}^{+} \rightarrow \mathrm{HO}_{2} \\
\mathrm{HO}_{2}^{-}+\mathrm{HO}_{2}^{-} \rightarrow \mathrm{H}_{2} \mathrm{O}_{2}+\mathrm{O}_{2} \\
\mathrm{H}_{2} \mathrm{O}_{2}+e_{\mathrm{CB}}^{-} \rightarrow \mathrm{OH}+\mathrm{OH}^{-} \\
\mathrm{H}_{2} \mathrm{O}_{2}+\mathrm{O}_{2}^{-} \rightarrow \mathrm{OH}+\mathrm{OH}^{-}+\mathrm{O}_{2} \\
\mathrm{H}_{2} \mathrm{O}_{2}+\mathrm{hv} \rightarrow 2 \mathrm{OH}^{\circ}
\end{gathered}
$$

$h^{+}$reactions:

$$
\begin{gathered}
h_{V B}^{+}+\mathrm{H}_{2} \mathrm{O} \rightarrow \mathrm{H}^{+}+\mathrm{OH} \\
\mathrm{OH}^{-}+h_{V B}^{+} \rightarrow \mathrm{OH}
\end{gathered}
$$

The redox reactions:

$$
\mathrm{HA}+\mathrm{O} \mathrm{H} \rightarrow \mathrm{H}_{2} \mathrm{O}+\mathrm{CO}_{2}+\text { other degradation products }
$$

$$
\begin{aligned}
& H A+\mathrm{TiO}_{2}\left(h_{V B}^{+}\right) \rightarrow \text { oxidation products } \\
& \mathrm{HA}+\mathrm{TiO}_{2}\left(e_{C B}^{-}\right) \rightarrow \text { reduction products }
\end{aligned}
$$

In summary, the molecular structures of HA can be broken down or rearranged by the photocatalysis process, which can convert the nonbiodegradable organics to more biodegradable forms.

\section{The Limitations}

Although it has been considered one of the most popular photocatalysts, the $\mathrm{TiO}_{2}$ material still has some of important limitations: 
Table 1. Comparative study on the efficiency of humic acid removal by using modified $\mathrm{TiO}_{2}$ photocatalyst.

\begin{tabular}{|c|c|c|c|c|}
\hline Type of modified $\mathrm{TiO}_{2}$ photocatalyst & $\begin{array}{c}\text { Removal } \\
\text { efficiency (\%) }\end{array}$ & Time & Kinetics model & References \\
\hline $\mathrm{Fe}_{2} \mathrm{O}_{3} / \mathrm{TiO}_{2} / \mathrm{GO}$ membrane & 98 & 2 hour & - & {$[20]$} \\
\hline $\mathrm{ZnO}$ coupled $\mathrm{TiO}_{2} /$ bamboo charcoal $\left(\mathrm{ZnO}-\mathrm{TiO}_{2} / \mathrm{BC}\right)$ & $\geq 99$ & 3 hour & Langmuir-Hinshelwood & {$[51]$} \\
\hline $\mathrm{TiO}_{2} / \mathrm{GAC}$ composite & 99.5 & 3 hour & Langmuir-Hinshelwood & {$[52]$} \\
\hline $\mathrm{TiO}_{2}$-coated ceramic foam filte (TCF) & 83 & 12 hour & - & {$[53]$} \\
\hline $\mathrm{TiO}_{2}$-coated membranes & $\approx 100$ & $80 \mathrm{~min}$ & Pseudo first-order kinetic & {$[54]$} \\
\hline $\mathrm{TiO}_{2}$-coated nanofibre membranes & 83 & 2 hour & - & {$[55]$} \\
\hline Photocatalytic Membrane Reactor (PMR) & 95 & 48 hour & - & {$[56]$} \\
\hline $\mathrm{Ag}-\mathrm{TiO}_{2} / \mathrm{HAP} / \mathrm{Al}_{2} \mathrm{O}_{3}$ & 88.3 & 1 hour & & [57] \\
\hline Fe-doped $\mathrm{TiO}_{2}$ & 50 & 1 hour & Pseudo first-order kinetic & {$[58]$} \\
\hline Ag-doped $\mathrm{TiO}_{2}\left(\mathrm{Z}-\mathrm{Na}-\mathrm{TiO}_{2}-\mathrm{Ag}\right)$ & 32 & 2 hour & - & [59] \\
\hline$\left(\mathrm{Cr}^{3+}+\mathrm{Ce}^{3+}\right)$ modified TiON $(\mathrm{Cr}-\mathrm{Ce} / \mathrm{TiON})$ & $\approx 99$ & 4 hour & Pseudo first-order kinetic & {$[60]$} \\
\hline$\left(\mathrm{TiO}_{2}\right)_{0.7}\left(\mathrm{RuO}_{2}\right)_{0.3}$ & 65 & 3 hour & - & {$[61]$} \\
\hline $\mathrm{TiO}_{2}$ thin film electrodes & 70 & $5 \mathrm{~min}$ & - & [62] \\
\hline
\end{tabular}

- $\mathrm{TiO}_{2}$ powder, called $\mathrm{TiO}_{2}$ Degussa P-25, is the most common commercial photocatalyst applied in the photocatalytic process. However, in the form of powder, $\mathrm{TiO}_{2}$ is not only easy to agglomerate but also difficult to recycle. It required a complication in the separation of powdered $\mathrm{TiO}_{2}$ after the treatment, which instantly raises the system's economic viability [47-49]. Alternatively, the catalyst may be attached to the suitable solid support without the need for separation from the effluent streams [50].

- Only ultraviolet light photons, which account for 4-5\% of the solar spectrum, have enough energy to displace valence band electrons due to the wide band gap of $\mathrm{TiO}_{2}$. Thus, photocatalytic activity is quite limited in visible, solar, and fluorescent light [51].

- During photocatalytic treatment processes, the rapid recombination of photogenerated electron-hole pairs is also a limitation that affects photocatalytic efficiency.

\section{Enhancement of HA Removal by the Modification of $\mathrm{TiO}_{2}$ Photocatalytic}

To overcome those limitations, in terms of removing $\mathrm{HA}$, many studies involving modified $\mathrm{TiO}_{2}$ photocatalytic have been carried out with certain success. The comparison of using a modified $\mathrm{TiO}_{2}$ photocatalyst for the removal of HA under various experimental conditions is compared in Table 1 [20, 51-62].

\section{Fixation of $\mathrm{TiO}_{2}$ onto the Support Matrix}

To solve the problem of $\mathrm{TiO}_{2}$ particle separation and recovery after the treatment, various techniques were done for the fixation of $\mathrm{TiO}_{2}$ onto the support matrix, e.g., dip-coating, sol-gel technique, filtration membrane, electrochemical oxidation, and chemical vapour deposition. When a photocatalytic film is used, most of the slurry drawbacks may be avoided.

Bamboo charcoal (BC) was used by Wang et al. [51] to invest in an effective photocatalyst for HA removal. $\mathrm{ZnO}$ coupled $\mathrm{TiO}_{2} / \mathrm{BC}$ with high adsorption-photocatalytic activity were synthesized by a microwave-assisted solgel method. The results showed that the $\mathrm{ZnO}-\mathrm{TiO}_{2} / \mathrm{BC}$ had relatively higher photodegradation efficiency for HA under visible-light irradiation as compared with $\mathrm{TiO}_{2} / \mathrm{BC}$. The synergistic relationship between surface adsorption characteristics and photocatalytic potential was also investigated by Xue et al. [52]. The nano-sized $\mathrm{TiO}_{2}-$ coated granular activated carbon composite $\left(\mathrm{TiO}_{2} / \mathrm{GAC}\right)$ was prepared by a sol-dipping-gel route using tetra- $n$ butyl titanate as the precursor. Due to its high surface area feature and high adsorption capacity, a suitable pore structure has proven the extensive exhaustive activated carbon as a supporter of $\mathrm{TiO}_{2}$ photocatalytic. Additionally, Mori et al. [53] investigated the photodecomposition of aqueous $\mathrm{HA}$ by a $\mathrm{TiO}_{2}$-coated ceramic foam filter (TCF) reactor. A remarkable result was given and high stability in consecutive operation cycles was also shown by the TCF reactor.

Along with the aim of enhancing photoactivity, the nanoscale of $\mathrm{TiO}_{2}$ has also been widely studied [63] due to its high specific surface area and sorption capacity for ionic and nonionic species [64]. Re-designing $\mathrm{TiO}_{2}$ structured photocatalytic material as well as incorporating $\mathrm{TiO}_{2}$ into the membrane, the slurries' drawbacks could be solved. The $\mathrm{TiO}_{2}$ membrane can provide unique multifunctional concurrent separation and photocatalytic degradation, thus no extra separation is needed. Besides, membrane fouling caused by 
NOM such as HA has been one of the major obstacles inhibiting the wide application of membrane technologies for water treatment. By confining the photocatalysts by means of a membrane, not only the above drawbacks of suspended nanoparticles can be overcome, it may also save energy, reduce the size of installation for catalyst separation, and reuse the photocatalyst in further runs [65]. The HA removal was increased by using membranes coated with $\mathrm{TiO}_{2}$ under $\mathrm{UV}_{254}$ (ultraviolet light of $\lambda=254$ $\mathrm{nm}$ ) irradiation in the investigation of Zhang et al. [54]. Via a concurrent filtration and photocatalytic oxidation, the $\mathrm{TiO}_{2}$ nanowire membrane achieved near $100 \%$ and 93.6\% removal rates of $\mathrm{HA}$ and total organic carbon (TOC), respectively. It can be explained by molecular weight cut-off of membranes becoming smaller with the presence of $\mathrm{TiO}_{2}$, which increased adsorption of HA. Additionally, the concurrent photocatalytic degradation led to a decrease of $\mathrm{TiO}_{2}$ nanowire membrane fouling caused by $\mathrm{HA}$ accumulation. Nanofiber membranes containing $\mathrm{TiO}_{2}$ nanoparticles were also used by Daels et al. [55], which stated that the removal of HA achieved $83 \%$ after $2 \mathrm{~h}$ of illumination. Taking a step forward, Patsios et al. [56] investigated the performance of a hybrid photocatalysis-membrane system that combined suspended $\mathrm{TiO}_{2}$ particles and an ultrafiltration submerged module for the removal of HA and control of membrane fouling. The efficiency of HA mineralization rate reached rather high - almost $74 \%$ at optimum $\mathrm{pH}$ near 5.5. In addition, the formation potential of DBPs was reduced because HA aromatic rings were degraded very high, resulting in more than $95 \%$ of specific UV-A ${ }_{254}$ removal efficiency in almost all cases studied. To further improve the effectiveness of the membrane process and reduce membrane fouling, Ma et al. [57] employed $\mathrm{Ag}^{-\mathrm{TiO}_{2}} /$ hydroxiapiate (HAP, $\left.\left.\mathrm{Ca}_{10}\left(\mathrm{PO}_{4}\right)_{6}(\mathrm{OH})_{2}\right) / \mathrm{Al}_{2} \mathrm{O}_{3}\right)$, which is a highly reactive photocatalytic membrane to carry out microfiltration (MF) coupling photocatalysis for removing HA. In this study, the HA removal of the membrane was improved but cannot be sustained because a limiting of transmembrane pressure seems to exist beyond. Additionally, the transition in fouling mode from initial pore blocking to cake filtration occurred much slower as UV irradiated.

Due to immobilization and $\mathrm{TiO}_{2}$-induced photodegradation, it can be concluded that membranes containing $\mathrm{TiO}_{2}$ nanoparticles provided several obvious advantages:

(i) Faster degradation of HA.

(ii) No requirement for separating and recycling catalyst particles.

(iii) Anti-fouling ability as a result of effective photocatalytic degradation of aromatic rings.

\section{Enhance Light Absorption}

With the limitation on the wide band gap of $\mathrm{TiO}_{2}$, numerous studies have been recently performed to improve photocatalytic activity and utilize solar energy more efficiently. To increase visible light absorption and $\mathrm{TiO}_{2}$ photocatalytic properties on HA removal, the doping of $\mathrm{TiO}_{2}$ with transition metal ions as well as with $\mathrm{Ag}$ and $\mathrm{Fe}$ have been studied to substitute $\mathrm{O}_{2}^{-}$in $\mathrm{TiO}_{2}$ to reduce the energy band-gap.

A great increase in the efficiency of solar light photocatalysis was explained by the extension of $\mathrm{TiO}_{2}$ absorption band from the UV into the visible region [66]. In a study by Birben et al. [58], a reduction in band gap energy of both bare P-25 and UV-100 $\mathrm{TiO}_{2}$ specimens to $2.55 \mathrm{eV}$ and $2.43 \mathrm{eV}$, respectively, was caused by Fe doping. In terms of solar photocatalytic activity in a period of $1 \mathrm{~h}$, approximately $50 \%$ of $\mathrm{HA}$ in UV absorbance at $254 \mathrm{~nm}$ was degraded by Fe-doped $\mathrm{TiO}_{2}$ specimens.

The expansion of absorption bands shifting to the visible range of $\mathrm{TiO}_{2}$ also was proved by Lazau et al. [59], who successfully synthesized the hybrid materials based on natural zeolite and undoped $\left(\mathrm{Z}-\mathrm{Na}-\mathrm{TiO}_{2}\right)$ and $\mathrm{Ag}$-doped $\mathrm{TiO}_{2}\left(\mathrm{Z}-\mathrm{Na}-\mathrm{TiO}_{2}-\mathrm{Ag}\right)$ by using solid-state reaction in microwave-assisted hydrothermal conditions. The result from UV-vis diffuse reflectance spectroscopy (DRUVVIS) showed that $\mathrm{Z}-\mathrm{Na}-\mathrm{TiO}_{2}-\mathrm{Ag}$ exhibited absorption within the range of visible light $(400-500 \mathrm{~nm})$, which is stronger than undoped $\mathrm{TiO}_{2}$ onto zeolite. In addition, under both ultraviolet and visible light irradiation, Z-Na$\mathrm{TiO}_{2}-\mathrm{Ag}$ had an enhanced photocatalytic activity on degradation and mineralization of $\mathrm{HA}$ in comparison with $\mathrm{Z}-\mathrm{Na}-\mathrm{TiO}_{2}$.

Another significant modification in the doping of $\mathrm{TiO}_{2}$ should be mentioned by Rashid et al. [60]. In this study, $\mathrm{N}$-doped $\mathrm{TiO}_{2}$, (TiON) was co-doped with bimetal $\left(\mathrm{Cr}^{3+}\right.$ and $\left.\mathrm{Ce}^{3+}\right)$. The bimetal-modified TiON $(\mathrm{Cr}-\mathrm{Ce} /$ TiON) catalyst with an evaluated bandgap of $2.1 \mathrm{eV}$ was successfully synthesized. The degradation of HA on exposure to visible light was done by the synthesized $\mathrm{Cr}-\mathrm{Ce} / \mathrm{TiON}$ catalyst.

These representative experiments verified that transition metal ions as well as with Fe, Ag doping of $\mathrm{TiO}_{2}$, shifts the $\mathrm{TiO}_{2}$ absorption band from the UV into the visible region and enhances the redox reaction.

\section{Delaying the Recombination of Photogenerated Electron-Hole Pairs}

Another general concern for $\mathrm{TiO}_{2}$ photocatalytic materials is the fast recombination of photogenerated electron-hole pairs, which would lead to the loss of photocatalytic activity [67-68]. Adjusting its structure or processing compositions is one way to delay the recombination of photogenerated electron-hole pairs, thus improving photocatalytic activity.

Graphene oxide (GO) was introduced into the $\mathrm{TiO}_{2}$ membrane matrix to improve the photocatalytic activity of $\mathrm{TiO}_{2}$ by functioning as an electron sink, suppressing the recombination of electron-hole pairs. Besides that, GO also showed strong adsorption of certain organic compounds in water, which may facilitate the photodegradation process [67]. Over 98\% HA removal in 
a short-term test $(2 \mathrm{~h})$ and $92 \%$ removal in a $12 \mathrm{~h}$ test under solar irradiation were the significant results when a membrane made of interconnecting $\mathrm{TiO}_{2}$ nanowires, $\mathrm{Fe}_{2} \mathrm{O}_{3}$ nanoparticles, and graphene oxide (GO) sheets was used by $\mathrm{Rao}$ et al. [20]. With $\mathrm{Fe}_{2} \mathrm{O}_{3} / \mathrm{TiO}_{2} / \mathrm{GO}$ compositions, the greater adsorption of HA improved photocatalytic activity of $\mathrm{TiO}_{2}$, the recombination of electron-hole pairs could be delayed, thus resulting in HA removal being enhanced and suggesting the antifouling ability of this novel membrane.

Another concept for developing $\mathrm{TiO}_{2}$-based photocatalytics (PC) is called photoelectrocatalytic (PEC). The photoelectrocatalytic treatment process is the combination of electrochemical and photocatalytic treatment processes [69-70]. In this method, a coating semiconductor onto a metal foil creates a photoanode that is biased by an external potential under illumination. The recombination of electron $\left(e_{C B}^{-}\right)$and hole $\left(h_{V B}^{+}\right)$is decreased by photoanode since the biasing potential applied, thus photocatalytic performance is improved. At the same time, photoexcited electrons can be withdrawn to a counter electrode in a cathode cell. Pinhedo et al. [61] used a titanium anode coated with 70\% $\mathrm{TiO}_{2}+30 \% \mathrm{RuO}_{2}\left(\left(\mathrm{TiO}_{2}\right)_{0.7}\left(\mathrm{RuO}_{2}\right)_{0.3}\right)$ in electrochemical and PEC oxidation methods for degradation of $\mathrm{HA}$ in aqueous solution. It stated that thermally prepared oxide electrodes exhibit photoactivity and may be used for photo-assisted electrolysis for the degradation of $\mathrm{HA}$ in aqueous effluents. By assisting electrolysis with photocatalysis, an increase in the HA degradation rate was observed. Taking over the conduct of the matter, Selcuk and Bekböle [62] continued to compare PC and PEC processes at acidic, neutral, and alkaline $\mathrm{pH}$ values. Once again, the effectiveness of PEC was more clearly confirmed. HA removal in the PEC process achieved two times under acidic conditions and four times under neutral conditions higher than the conventional PC process. After the lag phase, the TOC degradation rate of both PC and PEC process followed pseudo first-order kinetics. Rate constant in the PEC process was 2.4 times higher than in the PC process. Results of these studies proved that the PEC process was a safe and effective technique for decreasing DBP formation significantly in the removal of HA.

\section{Operational Parameters}

It has been demonstrated that the adsorption and the efficiency of the photocatalytic system are highly dependent on the operational parameters. Some reviews have been written regarding the mechanistic and kinetic details as well as the influence of experimental parameters [65, 71-73]. An understanding of the parameter effects not only aids in assessing the feasibility of using photocatalytic oxidation to HA removal but also allows for a thoughtful photocatalytic oxidation design. The most important operating parameters that govern the degradation rate and affect the photocatalytic
Table 2. Optimum dosage of $\mathrm{TiO}_{2}$ loading for degradation of $\mathrm{HA}$ from aqueous solution.

\begin{tabular}{|c|c|c|}
\hline Photocatalyst & $\begin{array}{c}\text { Optimum dosage } \\
\text { or optimal } \\
\text { thickness }\end{array}$ & References \\
\hline Degussa P25 & $1.5-2.0(\mathrm{~g} / \mathrm{L})$ & [19] \\
\hline $\begin{array}{l}\mathrm{Fe}_{2} \mathrm{O}_{3} / \mathrm{TiO}_{2} / \mathrm{GO} \text { membrane } \\
\text { (weight ratio of } 50: 100: 10 \text { ) }\end{array}$ & $15 \pm 1 \mu \mathrm{m}$ & {$[20]$} \\
\hline $\mathrm{ZnO}-\mathrm{TiO}_{2} / \mathrm{BC}$ & $2(\mathrm{~g} / \mathrm{L})$ & {$[51]$} \\
\hline $\mathrm{TiO}_{2} / \mathrm{GAC}$ & $2(\mathrm{~g} / \mathrm{L})$ & {$[52]$} \\
\hline $\begin{array}{l}\mathrm{TiO}_{2} \text { coated ceramic foam } \\
\text { filter }(\mathrm{TCF})\end{array}$ & $0.01 \% \mathrm{~g}^{-1} \mathrm{TiO}_{2}$ & {$[53]$} \\
\hline $\mathrm{TiO}_{2}$ nanowire membranes & $15 \mu \mathrm{m}$ & {$[54]$} \\
\hline Degussa P25 & $0.75(\mathrm{~g} / \mathrm{L})$ & {$[56]$} \\
\hline $\mathrm{Ag}-\mathrm{TiO}_{2}$ layer & $10-20 \mathrm{~nm}$ & {$[57]$} \\
\hline Fe-doped P-25 & $0.25(\mathrm{~g} / \mathrm{L})$ & {$[58]$} \\
\hline Fe-doped UV-100 & $0.25(\mathrm{~g} / \mathrm{L})$ & {$[58]$} \\
\hline Ag-Doped $\mathrm{TiO}_{2}$ & $1(\mathrm{~g} / \mathrm{L})$ & {$[59]$} \\
\hline $\mathrm{TiO}_{2}$ thin film electrodes & $0.5 \mathrm{~mm}$ & {$[62]$} \\
\hline Degussa P25 & $0.1(\mathrm{~g} / \mathrm{L})$ & {$[71]$} \\
\hline Degussa P25 & $0.25(\mathrm{~g} / \mathrm{L})$ & {$[75,76]$} \\
\hline
\end{tabular}

performance of $\mathrm{TiO}_{2}$ in $\mathrm{HA}$ removal can be summarized in the following sections.

$$
\mathrm{TiO}_{2} \text { Loading }
$$

The amount of catalyst loading is directly proportional to the overall photocatalytic reaction rate [74]. Generally, it is necessary to determine the optimum catalyst concentration in any given photocatalytic application in order to avoid excess catalyst and ensure total absorption of efficient photons. There is a higher surface area of the catalyst that is available for adsorption and degradation when the $\mathrm{TiO}_{2}$ catalyst loading is increased, leading to a corresponding increase in the decomposition process. The linear dependency is held to a certain extent when the amount of $\mathrm{TiO}_{2}$ reaches a certain level (saturation stage), causing an independence of reaction rate with $\mathrm{TiO}_{2}$ loading. It is understood that an increase of the photocatalyst concentration increases the solution opacity, leading to a reduction of light penetration in the solution, the surface area of $\mathrm{TiO}_{2}$ being exposed to light illumination and photocatalytic efficiency. Therefore, the optimum dosages of $\mathrm{TiO}_{2}$ loading selected below the saturation level, under given conditions, is very important to avoid excess catalyst and ensure efficient photon absorption. There are many studies given in Table 2 [19-20, 51-54, 56-59, 62, 71, 75-76] that have reported the effect of $\mathrm{TiO}_{2}$ loadings on the HA removal process efficiency. The optimal $\mathrm{TiO}_{2}$ catalyst dosage is mostly independent and it is difficult to make 
a direct comparison due to the experiment conditions, radiation fluxes, intensity, and wavelengths, and the dimension of the photoreactor used were different. For $\mathrm{TiO}_{2}$ immobilized systems, the optimal thickness of the catalyst film should also be considered due to $\mathrm{TiO}_{2}$ thin-film electrode being immobilized as a ceramic film. An excess increase of catalyst film thickness will increase the recombination possibility of the electron/ hole pair and the degradation performance is reduced, as an inevitability.

\section{Nature of the $\mathrm{TiO}_{2}$ Photocatalyst}

$\mathrm{TiO}_{2}$ has three different crystalline forms, with anatase and rutile being the most common while brookite forms are uncommon, unstable, and hence are not discussed in terms of catalyst materials [66]. Degussa $\mathrm{P}-25$, a powder including both forms of approximately $25 \%$ rutile and $75 \%$ anatase crystallites, is the most common commercially available form of $\mathrm{TiO}_{2}$ that has been used in many studies of photocatalytic degradation. By heating to temperatures above $700^{\circ} \mathrm{C}$, anatase $\mathrm{TiO}_{2}$ can be converted to rutile form. It is generally accepted that anatase is a better photocatalyst than rutile [77]. In addition, a number of different forms of $\mathrm{TiO}_{2}$ such as Degussa P-25, Hombikat UV100 (100\% anatase) have been synthesized to perform the desired characteristics of the photocatalyst. It was noted that the actual photocatalytic rate did not necessarily require the dependency on the higher surface area of Hombikat UV-100, but rather to the available or active sites or centers taking place in the course of the reaction. The probable reason for this occurrence could be explained by the unified crystal characteristics of Degussa P-25. In fact, Degussa P-25 composed of small nanocrystallites of rutile being dispersed within an anatase matrix. Thus, electron-hole pairs are generated by the smaller bandgap of rutile "catches" the photons. The transmission of the electron from the rutile conduction band to electron traps in the anatase phase takes place. This transmission inhibits the recombination and allows the hole to move to the surface of the particle and join the reaction. The better efficiency of Degussa P25 may also be explained by "quantum size effect" [78]: when the particles become too small, there is a "blue shift" with an increase of the band gap energy, detrimental to the near UV-photon absorption, and an increase of the electron-hole recombination. Not only that, in the report of Zhang et al. [79], two types of $\mathrm{TiO}_{2}$ obtained by the post-calcination of hydrothermally derived titanates were found to be more efficient than Degussa P-25 in the degradation of HA. In summary, morphological and crystallographic properties of $\mathrm{TiO}_{2}$ might play important roles in the photocatalytic efficiencies.

\section{Effect of $\mathrm{pH}$}

There are many reports about the effect of $\mathrm{pH}$ on photocatalytic degradation of organic compounds in aqueous solution [65, 72-73]. In fact, the interpretation of the $\mathrm{pH}$-dependent photodegradation of $\mathrm{HA}$ on $\mathrm{TiO}_{2}$ is a very difficult task because of its multiple roles.

First, relating to the ionization state, the surface of the $\mathrm{TiO}_{2}$ can be protonated or deprotonated under acidic or alkaline conditions [74], respectively, according to the following reactions:

$$
\begin{gathered}
\text { At } \mathrm{pH}<\text { PZC: } \mathrm{TiOH}+\mathrm{H}^{+} \leftrightarrow \mathrm{TiOH}_{2}^{+} \\
\text {At } \mathrm{pH}>\text { PZC: } \mathrm{TiOH}+\mathrm{OH}^{-} \leftrightarrow \mathrm{TiO}^{-}+\mathrm{H}_{2} \mathrm{O}
\end{gathered}
$$

The change of $\mathrm{pH}$ value can influence the adsorption modes of HA molecules onto the $\mathrm{TiO}_{2}$ surfaces, and the amount of produce $(\mathrm{OH})$ can lead to a modification of the overall photocatalytic oxidation rate. The $\mathrm{pH}$ value at which the number of the positively and negatively charged surface sites are equal is defined as the point of zero charge value $\left(\mathrm{pH}_{\mathrm{pzc}}\right)$ or isoelectric point. The $\mathrm{PZC}$ for $\mathrm{TiO}_{2}$ varies in the $\mathrm{pH}$ range of 6.0-7.5 [80], depending on the catalysts used. This means that the surface of the $\mathrm{TiO}_{2}$ is positively charged if $\mathrm{pH}$ is lower than the $\mathrm{PZC}$, while it is negatively charged if $\mathrm{pH}$ is higher than PZC. According to Teow et al. [18], it was clear that the coverage of $\mathrm{HA}$ on the $\mathrm{TiO}_{2}$ catalyst surface was obviously $\mathrm{pH}$-dependent. A strong ability to absorb $\mathrm{HA}$ on $\mathrm{TiO}_{2}$ particles is demonstrated at low $\mathrm{pH}$ condition $(\mathrm{pH}<3.0$ or 5.0$)$, whereas high solution $\mathrm{pH}$, the adsorption of HA, becomes very difficult. Teow et al. [18] showed that there is less than $5 \%$ of absorbance occurring at each PVDF-TiO 2 mixed-matrix membrane (MMMs) at $\mathrm{pH}$ 9.0. The negative influence on the permeate flux and HA removal at alkaline conditions ( $\mathrm{pH}$ 9.0) was confirmed by Szymański et al. [19], while at pH 3.0 and pH 6.5 no membrane fouling was noticed. In acidic solution (close to $\mathrm{pH}_{\mathrm{zp}}$ ), HA molecules are easily adsorbed on the surface of $\mathrm{TiO}_{2}$ and are more quickly mineralized. A near optimum $\mathrm{pH}$ at approximately 5.5 was also identified by Patsios et al. [56], with high mineralization rate of $\mathrm{HA}$ as well as high mineralization efficiency (almost $74 \%$ ). Palmer et al. [81] also observed that the maximum mineralization rate was close to $\mathrm{pH} 7$.

In the case of doped or coated photocatalysts, a change in $\mathrm{pH}$ may change the interfacial structure. Both of $\mathrm{ZnO}-\mathrm{TiO}_{2} / \mathrm{BC}$ and $\mathrm{TiO}_{2} / \mathrm{BC}$ composites in Wang et al. [51] showed that the removal efficiency of HA decreased as $\mathrm{pH}$ increased from 2.0 to 10.0. In addition, at $\mathrm{pH}>\mathrm{PZC} 7.2$ and 8.1, HA could not adsorb onto the negatively charged $\mathrm{ZnO}-\mathrm{TiO}_{2} / \mathrm{BC}$ and $\mathrm{TiO}_{2} / \mathrm{BC}$ surfaces, respectively. Xue et al. [52] also confirmed that HA cannot adsorb onto the negatively charged $\mathrm{TiO}_{2} / \mathrm{GAC}$ surface at high $\mathrm{pH}$ values.

Secondly, the $\mathrm{pH}$ affects not only the adsorption of charged contaminants but also alters the concentration of surface hydroxyls and shifts the position of conductance and valence bands [80]. It is hard to predict the effect of $\mathrm{pH}$ on the band edges of the $\mathrm{TiO}_{2}$ and the oxidation potential of HA [81]. 
The third role is hydroxyl radicals $(\mathrm{OH})$ can be formed by the reaction between hydroxide ions and positive holes (Eq. (9)). At neutral or high $\mathrm{pH}$ levels, ${ }^{\circ} \mathrm{OH}$ radicals are considered the pre-dominant species, which means are more easily generated due to more ions being available on the $\mathrm{TiO}_{2}$ surface, and thus the efficiency of the process is enhanced [82]. On the other hand, the positive holes act as the major oxidation species at low $\mathrm{pH}$. However, $\cdot \mathrm{OH}$ radicals can also be generated following the pathway presented by Eqs. (3)-(7), and this mechanism at lower $\mathrm{pH}$ should also be taken into consideration [65]. The importance of ${ }^{\circ} \mathrm{OH}$ in the photocatalytic oxidation of HA was emphasized by Liu et al. [83]. At low $\mathrm{pH}$, the overall HA removal process was not improved by the enhancement of HA adsorption. The reaction rate could be enhanced by the addition of $\mathrm{H}_{2} \mathrm{O}_{2}$ further due to the increased generation of ${ }^{\circ} \mathrm{OH}$.

Finally, $\mathrm{TiO}_{2}$ particles tend to agglomerate at low $\mathrm{pH}$ and the surface area available for adsorption of contaminants and photon absorption would be reduced, which finally influences the photodegradation rate [80]. The aggregation of $\mathrm{TiO}_{2}$ nanoparticles in an aquatic environment under UV irradiation at different $\mathrm{pH}$ levels was investigated by Wang et al. [84]. With the same period of $U V$, the highest aggregation was observed at $\mathrm{pH}$ 3.0. Furthermore, the results illustrated that the removal of the HA was in accordance with the $\mathrm{TiO}_{2}$ aggregation time. Because of this reason, $\mathrm{pH}$ plays an important role both in the characteristics of the aqueous solution and in the reaction mechanisms such as hydroxyl radical attack, direct oxidation by the positive hole, and direct reduction by the electron.

Since the effect of $\mathrm{pH}$ is very complicated and complex, as can be seen from the above discussion, the optimal $\mathrm{pH}$ value for a specified application should be selected on the basis of preliminary investigations.

\section{Effect of Reaction Temperature}

In fact, photocatalytic systems in most cases are operated at room temperature and do not require heating. Although it is well known that the minor changes in temperature do not much affect the photocatalytic oxidation rate, many researchers are establishing experimental evidence for the dependence of photocatalytic activity on temperature. At room temperature, low thermal energy $(0.026 \mathrm{eV})$ is inadequate to activate the $\mathrm{TiO}_{2}$ surface, but it is quite close to the activation energy of hydroxyl radical formation. Thus, it can be assumed that the photodegradation rate of HA is governed by hydroxyl radical reactions, and the effect of temperature on the rate of oxidation may be dominated by the rate of interfacial electron transfer to oxygen.

At a reaction temperature greater than $80^{\circ} \mathrm{C}$ and that tends to the boiling point of water, the recombination of charge carriers would be enhanced and the adsorption of HA compounds onto the $\mathrm{TiO}_{2}$ surface is disfavored and becomes the rate-limiting step, resulting in a decrease of photocatalytic activity [74]. On the contrary, a low temperature below $80^{\circ} \mathrm{C}$ actually favors adsorption, which enhances the adsorption of final reaction products. At very low temperatures (below $0^{\circ} \mathrm{C}$ ), the photocatalytic activity would be decreased and desorption becomes the rate-limiting step of the process. As a consequence, the temperature range between $20-80^{\circ} \mathrm{C}$ has been regarded as the desired temperature for effective photomineralization of organic content.

The Van't Hoff-Arrhenius equation (Eq. (15)) has been applied to describe the effect of reaction temperature on the rate constant $k$, which is linearly proportional to the exponential $(-1 / \mathrm{T})$ :

$$
\ln \left(\frac{k_{1}}{k_{2}}\right)=-\frac{E_{a}}{R}\left(\frac{1}{T_{2}}-\frac{1}{T_{1}}\right)
$$

...where $E_{a}$ is the energy of activation, $R$ is the universal gas constant, and $k_{1}$ and $k_{2}$ are the constants for temperatures $T_{1}$ and $T_{2}$, respectively. However, the data in Palmer et al. [81]'s experiment did not fit the Arrhenius equation well.

\section{Light Wavelength}

In the photocatalytic process, depending on the types, the crystalline phase or modifications state of photocatalysts used, radiation sources with different wavelength-emitting ranges is an important ingredient in the reaction rate. With $\mathrm{TiO}_{2}$, which absorbs irradiation below the visible range of the light spectrum, a light wavelength at least near UV light is needed. The band gap of anatase $\mathrm{TiO}_{2}$ is $3.2 \mathrm{eV}$ and the irradiation portion is below $380 \mathrm{~nm}$, which is sufficient for photonic activation. Depending on the band gap threshold of the type used, the rutile $\mathrm{TiO}_{2}$ can be activated with the light wavelength of up to $400 \mathrm{~nm}$ due to its band gap being $3.02 \mathrm{eV}$.

The light sources might be solar irradiation or artificial lamps. Solar light can also activate $\mathrm{TiO}_{2}$ given that the $\mathrm{TiO}_{2}$ activation spectrum overlaps with the solar spectrum. Unfortunately, only $4-5 \%$ of the total irradiated natural sunlight reaching the earth's surface is in the 300-400 nm near ultraviolet (UV) range that has sufficient energy that can be used to power photocatalytic reactors. This wavelength-emitting range is suitable for photocatalytic degradation of water pollutants. Several experiments were carried out for removing HA in solar photoreactors. By using UV light and artificial sunlight (ASL), Dziedzic et al. [85] studied the effects of wavelength on photocatalytic degradation of HA. It was stated that the removal efficiency of HA under ASL irradiation was only $18 \%$, whereas the removal under UV irradiation was found to be $100 \%$ as measured by the $\mathrm{UV}_{254}$ absorption technique. It means that the energy of the ASL appeared not to be high enough to cause the degradation of humic substances in a photocatalytic process at the $\mathrm{TiO}_{2}$ surface.

However, a drawback of solar energy is its intermittency and variability, with both factors being geographically dependent. Therefore, numerous investigations have 
recently been focused on the preparation of novel photocatalysts that are able to utilize the visible range of the solar spectrum [86]. To increase the efficiency of solar light photocatalysis, doping of $\mathrm{TiO}_{2}$ with transition metal ions has been considered an effective method that to red-shift the $\mathrm{TiO}_{2}$ absorption band from the UV into the visible region. It was demonstrated through $\mathrm{Fe}$-doped $\mathrm{TiO}_{2}$ and $\mathrm{Fe}_{2} \mathrm{O}_{3} / \mathrm{TiO}_{2} / \mathrm{GO}$ compositions in the study of Rao et al. [20] and Birben et al. [58], respectively.

It could be concluded that the range of light absorbed is one of the most important factors for photocatalyst. Although UV-based photocatalysts perform better than visible light-based photocatalysts due to the higher photon energy, visible light reaches the Earth's surface much more than UV light. Thus, a less efficient photocatalyst that absorbs visible light may ultimately be more useful than a more efficient photocatalyst absorbing solely light with smaller wavelengths.

\section{Light Intensity}

Light intensity has a determinant role in the kinetics of the photocatalysis process. The review of Konstantinou and Albanis [82] reported that during a photocatalytic process:

i. In the case of low light intensities $\left(0-20 \mathrm{~mW} / \mathrm{cm}^{2}\right)$, the rate would increase linearly with increasing light intensity (first order), because the electron-hole was mainly formed from the reactions involved, while electron-hole recombination is negligible.

ii. In the case of intermediate light intensities beyond a certain value (approximately $25 \mathrm{~mW} / \mathrm{cm}^{2}$ ), the rate would depend on the square root of the light intensity (half order), because there is a lower effect on the reaction rate caused by the competition between electron-hole pair separation and recombination.

iii. In the case of high light intensities, the rate is independent of light intensity, which is explained as follows: due to the surface coverage of the catalyst being saturated, resulting in a mass transfer in the adsorption and desorption being limited, it thus prevents the effect of light intensity from setting in.

In recent studies, the enhancement of reaction rate in $\mathrm{HA}$ removal in the presence of $\mathrm{TiO}_{2}$ and $\mathrm{UV}$ wavelength as the light intensity increased was also observed [57, 71, 82]. By using nominal $\mathrm{TiO}_{2}$ particles without modifications, Palmer et al. [81] showed that due to the increasing number of oxidizing species, the rate of degradation of HA also increases as light intensity increases, and there were two regions of light intensity increase results in differing degrees of the rate increase. Pansamut et al. [71] used commercial $\mathrm{TiO}_{2}$ Degussa P-25 as a photocatalyst for investigating the effect of light intensity to the kinetics of photocatalytic degradation of HA. The results reported that $99 \%$ of HA removal efficiency was found and the removal efficiency increased with increasing light intensity and then become asymptotic. Under given feed water composition, increasing light intensity, which is helpful for HA removal from aqueous solution, also was proved by Ma et al. [57] with a highly reactive photocatalytic membrane (Ag-TiO 2 /hydroxiapiate $\left(\mathrm{HAP}, \mathrm{Ca}_{10}\left(\mathrm{PO}_{4}\right)_{6}(\mathrm{OH})_{2}\right) / \mathrm{Al}_{2} \mathrm{O}_{3}$ ).

In summary, intensity increase proportionally with the reaction rate until it reaches the mass transfer limit (case (iii)). At higher irradiation intensities the electron transfer from the catalyst to oxygen present in the solution, which results in the generation of, is the rate-limiting step, especially in the case of larger $\mathrm{TiO}_{2}$ particles and photocatalyst agglomerates.

\section{Dissolved Oxygen}

Dissolved oxygen (DO) has been essential to semiconductor photocatalytic degradation of organic compounds. It was found that the presence of DO might restrict or improve the photodegradation rate depending on the degradation mechanism of the pollutant. DO is strongly electrophilic, which serves as the electron scavenger to trap the excited conduction-band electron from recombination in the photodegradation processes [87]. But higher concentrations of DO may lead to decreasing the reaction rate due to the $\mathrm{TiO}_{2}$ surface becoming highly hydroxylated to the extent of inhibiting the adsorption of pollutants at active sites. Generally, Henry's Law can be simulated to find an approximation of the amount of DO under the experimental conditions, provided the oxygen sparging rate and the photoreactor gas holdup is known [88]. Photoreactor sparging with pure oxygen in the $\mathrm{TiO}_{2}$ slurry reactor is usually a costineffective solution, as the amount of DO being held-up is a function of photoreactor geometry [72]. Therefore, it should be considered for operating the photoreactor under ambient conditions in order to prevent raising the cost of air or oxygen sparging for enhanced degradation rates.

In other words, DO is not only one of an electron acceptor but also involves the formation of other reactive oxygen species and the stabilization of radical intermediates, mineralization, and direct photocatalytic reactions [72]. This was evidenced by the research of Palmer et al. [81] for HA degradation and mineralization rates. The degradation occurred with the presence of alternative electron acceptors, but there was no carbon dioxide released, suggesting that oxygen was required for mineralization.

\section{Concentration and Nature of HA}

Numerable studies have shown that the rate of photocatalytic degradation of an organic pollutant depends on its concentration, nature such as its structure, molar mass, functional groups, and other existing compounds in aqueous solution [87-88].

In general, under similar operating conditions, organic pollutants increase the photocatalytic degradation rate to a certain level with the increase of its initial concentration. However, a further increase in the concentration creates 
the saturation on the $\mathrm{TiO}_{2}$ surface and the deactivation of the photocatalyst, leading to a decrease of the degradation rate [74, 82]. Yigit and Inan [89] showed that increasing initial HA concentration decreases photocatalytic degradation efficiency. This indicates that the breakdown of some conjugated carbon structures leads to the fragmentation of high molecular weight of organic substances into smaller units. Most researchers have applied the Langmuir-Hinshelwood model to describe the effect of organics concentration on degradation rate. In the case of Palmer et al. [81], the rate of degradation increased with increasing initial concentration of HA until the concentration of $30 \mathrm{ppm}$ carbon, and after this concentration the rate actually decreased. The data did not follow Langmuir-Hinshelwood kinetics model but was actually slightly concave in nature.

Furthermore, the chemical structure of the HA compound also influences the degradation rate of the photocatalytic reactor. HA are organic macromolecules formed with a high molecular weight and that act as natural photosensitizers, which could participate both as electron donor centers (oxidation) and as an electron accepting centers (reduction). Therefore, sequential electron transfer, which from excited $\mathrm{HA}$ to the $\mathrm{TiO}_{2}$ conduction band could lead to mineralization with $\mathrm{CO}_{2}$ evolution, while that from the $\mathrm{TiO}_{2}$ conduction band to $\mathrm{HA}$ tends to inhibit mineralization. In addition, the structure, molar mass, and functional groups of HA were used in different investigations, which may vary according to the source, age, interactions with the environment, and extraction process. This was well demonstrated in the work of Uyguner and Bekböle [75] and Erhayem and Sohn [90], whereas the adsorption of $\mathrm{HA}$ on $\mathrm{TiO}_{2}$ in various sources and environmental exposures was measured. By using $\mathrm{TiO}_{2}$ Degussa P-25, Uyguner and Bekböle [75] investigated the photocatalytic removal efficiencies of humic and fulvic acids from different origins (terrestrial and aquatic). Based on the source of origin, whereas diverse chemical and physical properties such as molecular weight, molecular size, and elemental composition, the efficiencies of removal humic and fulvic acids were different for each compound.

On the other hand, synchronous scan fluorescence (SSF) spectroscopy was used to complement the study of $\mathrm{HA}$ adsorption onto $\mathrm{TiO}_{2}$ nanoparticles by Erhayem and Sohn [90]. In this study, there are six kinds of HA that were derived from soils (SLHAs) or sediments (SDHAs), and all originating from the state of Florida. Overall, because of structural differences, the soil HA affected the environmental stability and mobility of nano- $\mathrm{TiO}_{2}$ differently than did sedimentary HA. The SSF spectra also indicated that there was preferential adsorption of polycondensed structures, which are more prevalent in soil HA than in sedimentary HA.

\section{Inorganic Ions}

An aqueous solution is often quite complex and contains a mixture of inorganic and organic solvents as well as dissolved inorganic matter and humic substances. The dissolved inorganic species (as anions and cations) can be adsorbed or compete for the active sites on the $\mathrm{TiO}_{2}$ surface and, subsequently, affect the photocatalytic degradation rate of the organic pollutants $[19,76,80]$ or may lead to voluntary photochemical phenomena. Hence, the influence of inorganic compounds on the $\mathrm{TiO}_{2}$ photocatalytic properties has become an important research field.

\section{Effect of Inorganic Anions}

The inorganic anions naturally occurring in aqueous solution, such as $\mathrm{Cl}{ }^{-}, \mathrm{NO}_{3}^{-}, \mathrm{SO}_{4}{ }_{4}^{2-}, \mathrm{CO}_{3}{ }^{2-}$, $\mathrm{HCO}_{3}^{-}$, and $\mathrm{PO}_{4}^{3-}$ are known to inhibit the surface activity of the $\mathrm{TiO}_{2}$ catalyst [64]. These anions behave as holes $h^{+}$and ${ }^{\circ} \mathrm{OH}$ scavengers, subsequently, the inorganic anion radicals (e.g. $\mathrm{Cl}{ }^{\circ}, \mathrm{NO}_{3}{ }^{*}$ ) are formed, whereas the reaction mechanism was obtained as follows:

$$
\begin{gathered}
\mathrm{Cl}^{-}+\mathrm{OH}^{\cdot} \rightarrow \mathrm{Cl}+\mathrm{OH}^{-} \\
\mathrm{Cl}^{-}+\mathrm{h}^{+} \rightarrow \mathrm{Cl}
\end{gathered}
$$

These inorganic anion radicals may initiate oxidation reactions with organic species under $\mathrm{CO}_{2}$ formation. Although the reactivity of these radicals may be considered, they are not as reactive as $h^{+}$and ${ }^{\circ} \mathrm{OH}$, thus the observed retardation effect is still thought to be the strong adsorption displacement mechanism, which results in reducing the number of available on the $\mathrm{TiO}_{2}$ surface $[65,82]$.

The effect of common inorganic anions on the photocatalytic degradation of HA was studied by Birben and Bekböle [76]. In this study, a representative range of common anions was added to HA solution in the presence of $\mathrm{TiO}_{2}$ Degussa P-25. The collected data indicated the presence of anions' significantly enhanced initial adsorption on $\mathrm{TiO}_{2}$ surface, thus the percentage removed of HA decreased. In addition, there was an inhibitory effect on the HA removal in terms of DOC and $\mathrm{UV}_{254}$ as increasing anion concentration. The binding of inorganic anions with the catalyst may form fouling, as shown by Szymański et al. [19]. It was found that the presence of $\mathrm{HCO}_{3}^{-}$, $\mathrm{SO}_{4}^{2-}$, and $\mathrm{HPO}_{4}^{2-}$ decreases the flux just at the beginning of the process at both low and high concentrations of these species. In other words, the membrane fouling was formed more severely by these species, resulting in a lower efficiency of HA removal in the feed.

\section{Effect of Inorganic Cations}

The metal ion is incorporated into the $\mathrm{TiO}_{2}$ lattice, therefore impurity energy levels in the band gap of $\mathrm{TiO}_{2}$ are formed (Eq. (18)-(19)): 


$$
\begin{aligned}
& M^{n+}+h v \rightarrow M^{(n+1)+}+e_{C B}^{-} \\
& M^{n+}+h v \rightarrow M^{(n-1)+}+h_{V B}^{+}
\end{aligned}
$$

...where $\mathrm{M}$ is metal and $\mathrm{M}^{n+}$ is metal ion. Moreover, electron (hole) transfer between metal ions and $\mathrm{TiO}_{2}$ can modify the electron-hole recombination:

$$
\begin{array}{ll}
M^{n+}+e_{C B}^{-} \rightarrow M^{(n-1)+} & \text { as electron trap (20) } \\
M^{n+}+h_{V B}^{+} \rightarrow M^{(n+1)+} & \text { as hole trap }
\end{array}
$$

Due to its ability to trap either electrons or holes via oxidizing and reducing reactions, metal ions may increase the photocatalytic rate.

The effect of metal ions $\mathrm{Ca}^{2+}$ and $\mathrm{Mg}^{2+}$ on the photocatalytic oxidation of $\mathrm{HA}$ in $\mathrm{TiO}_{2}$ suspensions was investigated by $\mathrm{Li}$ et al. [91]. They concluded that cation strength was created by adding positively charged metal ions, increasing the efficiency of $\mathrm{TiO}_{2}$. While the $\mathrm{pH}$ of the aqueous solution was close to the $\mathrm{PZC}$ of $\mathrm{TiO}_{2}$, the photocatalytic oxidation could be enhanced by the effect of $\mathrm{Ca}^{2+}$ on the adsorption between $\mathrm{HA}$ and $\mathrm{TiO}_{2}$. On the other hand, the rate of HA removal was significantly enhanced in the presence of either $\mathrm{Ca}^{2+}$ or $\mathrm{Mg}^{2+}$. It took less than $1 \mathrm{~h}$ to achieve the same removal HA efficiency in comparison with more than $2.5 \mathrm{~h}$ in the reaction without the addition of $\mathrm{Ca}^{2+}$ or $\mathrm{Mg}^{2+}$.

Szymański et al. [19] investigated HA removal by using a ceramic UF membrane in a photocatalytic membrane reactor. They found that there was a more efficient adsorption of $\mathrm{HA}$ on $\mathrm{TiO}_{2}$ particles and reduced membrane fouling in the presence of and .

These experimental results further proved that the existence of divalent cationic ions in HA aqueous solution could enhance the adsorption rate of HA on the $\mathrm{TiO}_{2}$ surface and therefore improve the photoreduction rate.

\section{Conclusions and Future Prospects}

The association between the $\mathrm{TiO}_{2}$ photocatalytic oxidation process and HA results in modification of the interactions, fate, transport, and toxicity of $\mathrm{TiO}_{2}$ particles. This review has attempted to summarize most of the literature concerning the removal of HA from aqueous solution by using $\mathrm{TiO}_{2}$ photocatalytic particles. Although there has been a great number studies that have achieved certain success in this area, the use of the $\mathrm{TiO}_{2}$-based particles for HA removal has still suffered from some major disadvantages. Further investigations are needed to focus on the key areas to overcome these shortcomings as follows:

- The low quantum efficiency due to the fast recombination of photo-generated charge carriers is one of the major drawbacks of the $\mathrm{TiO}_{2}$ photocatalyst. Any method that can enhance the lifetime of electron-hole pairs substantially increases the photocatalytic performance that should be devoted to future research.

- Despite so many research papers reporting on the effects of different modifications of the $\mathrm{TiO}_{2}$ surface to improve its photocatalytic activity, little work has been provided a high photoactivity and thermal stability particle that can utilize visible and/or solar light irradiation. Besides that, $\mathrm{TiO}_{2}$ under UV irradiation treatment is still considered a $\mathrm{pH}$-dependent process due to the surface-oriented nature of photocatalysis. Each modified $\mathrm{TiO}_{2}$ photocatalytic method achieves different effects along with certain limitations. Thus, researching an integrated system with wider $\mathrm{pH}$ range, with mixtures of the different methods for enhanced photomineralization or photo-disinfection kinetics and utilizing visible and/or solar light irradiation should be expanded further and applied in environmental protection.

- The toxicity of $\mathrm{TiO}_{2}$ nanoparticles increased in the presence of HA and thus should be considered. Moreover, it has been asserted that photocatalytic oxidation generates superoxide $\left(\mathrm{O}_{2}^{--}\right)$, and the hydroxide radical $\left({ }^{\circ} \mathrm{OH}\right)$ could be harmful to the human physiological system. Currently, there are no regulations related to the use of nanoparticle $\mathrm{TiO}_{2}$, which can accumulate and potentially have health impacts on workers exposed to nanoparticle $\mathrm{TiO}_{2}$ dust. On the other hand, it is difficult to separate the $\mathrm{TiO}_{2}$ particles from aqueous suspension after treatment. How to reduce the harmful effect both on human health and the environment by keeping its usual microbial activities may be worth further research.

- Most of the studies conducted on HA removal are based on the single HA model solution and therefore might not fully represent their actual efficiency in the real water matrix, where a mixture of the compound exists. More work concentrating on the effect of complex mixtures compound is thus required.

- Although there are large differences in $\mathrm{TiO}_{2}$ used and reaction operatational parameters (light source, catalyst loading, reaction time and type, the concentration of substrates, etc.), the comparison between each research is little. The respective data analysis was found to be very complex and different from others. Standardization of reactions with further optimization of reaction parameters is one important step that should be considered to get beyond the present level.

In summary, taking together all the above directional prospects in this field, a large-scale photocatalytic treatment process with high efficiency, solar-driven, environmentally friendly, and safe with human health should be realized in the near future. 


\section{Acknowledgements}

This work was supported by the Major Science and Technology Program for Water Pollution Control and Treatment of China $12^{\text {th }}$ Five-Year Plan (No. 2012ZX07101007-005), Hubei Provincial Natural Science Foundation of China (No. 2014CFB282), and the Knowledge Innovation Program of the Chinese Academy of Sciences. The authors would like to thank all my teachers as well as other laboratory colleagues in the School of Resources and Environmental Engineering, Wuhan University of Technology and in the laboratory of the Institute of Hydrobiology, Chinese Academy of Science for assistance during our work. Additionally, we appreciate the constructive suggestions of the anonymous reviewers, which were invaluable in improving the quality of the manuscript.

\section{Conflict of Interest}

The authors declare no conflict of interest.

\section{References}

1. MATILAINEN A., VEPSALAINEN M., SILLANPAA M. Natural organic matter removal by coagulation during drinking water treatment: A review. Advances in Colloid and Interface Science 159, 189, 2010.

2. MAGHSOODLOO SH., NOROOZI B., HAGHI A.K., SORIAL G.A. Consequence of chitosan treating on the adsorption of humic acid by granular activated carbon. Journal of Hazardous Materials 191, 380, 2011.

3. BHATNAGAR A., SILLANPAA M. Removal of natural organic matter (NOM) and its constituents from water by adsorption - A review. Chemosphere 166, 497, 2017.

4. FENG Q.Y., LI X.D., CHENG Y.J., MENG L., MENG Q.J. Removal of Humic Acid from Groundwater by Electrocoagulation. Journal of China University of Mining and Technology 17 (4), 513, 2007.

5. HASSAN K., BIJIAN B., JAVAD K. Evaluation of $\mathrm{UV} / \mathrm{TiO}_{2}$ Photo-Catalytic process for removing humic compounds from water. Polish Journal of Environmental Studies 24 (3), 1063, 2015.

6. YANG S., HU J., CHEN C., SHAO D., WANG X. Mutual effects of $\mathrm{Pb}(\mathrm{II})$ and humic acid adsorption on multiwalled carbon nanotubes/polyacrylamide composites from aqueous solutions. Environmental Science and Technology 45 (8), 3621, 2011.

7. LIU H., HU C., ZHAO H., QU J. Coagulation of humic acid by $\mathrm{PACl}$ with high content of $\mathrm{Al}_{13}$ : The role of aluminum speciation. Separation and Purification Technology 70, 225, 2009.

8. DUAN J., CAO X., CHEN C., SHI D., LI G., MULCAHY D., Effects of $\mathrm{Ca}(\mathrm{OH})_{2}$ assisted aluminum sulfate coagulation on the removal of humic acid and the formation potentials of tri-halomethanes and haloacetic acids in chlorination. Journal of Environmental Sciences (China) 24, 1609, 2012.

9. SUDOH R., ISLAM M.S., SAZAWA K., OKAZAKI T., HATA N., TAGUCHI S., KURAMINTZ H. Removal of dissolved humic acid from water by coagulation method using polyaluminum chloride (PAC) with calcium carbonate as neutralizer and coagulant aid. Journal of Environmental Chemical Engineering 3 (2), 770, 2015

10. BEN-SASSON M., ZIDON Y., CALVO R., ADIN A. Enhanced removal of natural organic matter by hybrid process of electrocoagulation and dead-end microfiltration. Chemical Engineering Journal. 232, 338, 2013.

11. GHERNAOUT D., MARICHE A., GHERNAOUT B., KELLIL A. Electromagnetic treatment doubled electrocoagulation of humic acid in continuous mode using response surface method for its optimisation and application on two surface waters. Desalin. Water Treat. 22, 311, 2010.

12. LABANOWSKI J., PALLIER V., FEUILLADECATHALIFAUD G. Study of organic matter during coagulation and electrocoagulation processes: Application to a stabilized landfill leachate. J. Hazard. Mater. 179, 166, 2010.

13. VEPSALAIINEN M., PULLIAINEN M., SILLANPAA M. Effect of electrochemical cell structure on natural organic matter (NOM) removal from surface water through electrocoagulation (EC). Sep. Purif. Technol. 99, 20, 2012.

14. ULU F., BARISCI S., KOBYA M., SARKKA H., SILLANPAA M. Removal of humic substances by electrocoagulation (EC) process and characterization of floc size growth mechanism under optimum conditions. Separation and Purification Technology 133, 246, 2014.

15. GHERNAOUT D., IRKI S., BOUCHERIT A. Removal of $\mathrm{Cu}^{2+}$ and $\mathrm{Cd}^{2+}$, and humic acid and phenol by electrocoagulation using iron electrodes. Desalin. Water Treat. 52, 3256, 2014.

16. LIAO A.A., SPITZER M., MOTHEO A.J., BERTAZZOLI R. Electrocombustion of humic acid and removal of algae from aqueous solutions. J. Appl. Electrochem. 38, 721, 2008.

17. WANG J.N., LI A.M., ZHOU Y., XU L. Study on the influence of humic acid of different molecular weight on basic ion exchange resin's adsorption capacity. Chinese Chemical Letters 20, 1478, 2009.

18. TEOW Y.H., OOI B.S., AHMAD A.L. Study on PVDF$\mathrm{TiO}_{2}$ mixed-matrix membrane behaviour towards humic acid adsorption. Journal of Water Process Engineering 15, 99, 2015.

19. SZYMANSKI K., MORAWSKI A.W., MOZIA S. Humic acids removal in a photocatalytic membrane reactor with a ceramic UF membrane, Chemical Engineering Journal. 305, 19, 2016.

20. RAO G., ZHANG Q., ZHAO H., CHEN J., LI Y. Novel titanium dioxide/iron(III)oxide/graphene oxide photocatalytic membrane for enhanced humic acid removal from water. Chemical Engineering Journal 302, 633, 2016.

21. RAUTHUlA M.S., SRIVASTAVA V.C. Studies on adsorption/desorption of nitrobenzene and humic acid onto/from activated carbon. Chemical Engineering Journal 168, 35, 2011.

22. WANG J., BI L., JI Y., MA H., YIN X. Removal of humic acid from aqueous solution by magnetically separable polyaniline: Adsorption behavior and mechanism. Journal of Colloid and Interface Science 430, 140, 2014.

23. WANG J., ZHOU Y., LI A., XU L. Adsorption of humic acid by bi-functional resin $\mathrm{JN}-10$ and the effect of alkaliearth metal ions on the adsorption. Journal of Hazardous Materials 176, 1018, 2010.

24. TANG Y., LIANG S., YU S., GAO N., ZHANG J., GUO H., WANG Y. Enhanced adsorption of humic acid on 
amine functionalized magnetic mesoporous composite microspheres. Colloids and Surfaces A: Physicochemical and Engineering Aspects 406, 61, 2012.

25. TAO Q., XU Z., WANG J., LIU F., WAN H., ZHENG S. Adsorption of humic acid to aminopropyl functionalized SBA-15. Microporous and Mesoporous Materials 131, 177, 2010.

26. PARK S., YOON T. I. The effects of iron species and mineral particles on advanced oxidation processes for the removal of humic acids. Desalination 208, 181, 2007.

27. LIU X., FITZPATRICK C.S.B. Removal of humic substances using solar irradiation followed by granular activated carbon adsorption. Water Science and Technology: Water Supply, 10 (1), 15, 2010.

28. U.S. ENVIRONMENTAL PROTECTION AGENCY. Handbook advanced photochemical oxidation processes. BiblioGov: Columbus, Ohio, 10, 2012.

29. BIBI I., NAZAR N., IQBAL M., KAMAL S., NAWAZ H., NOUREN S., SAFA Y., JILANI K., SULTAN M., ATA S., REHMAN F., ABBAS M. Green and eco-friendly synthesis of cobalt-oxide nanoparticle: Characterization and photo-catalytic activity. Advanced Powder Technology 28 (9), 2035, 2017.

30. HOZALSKI R.M., BOUWER E.J., GOEL S. Removal of natural organic matter (NOM) from drinking water supplies by ozone-biofiltration. Water Sci Technol. 40, 157, 1999.

31. WEI M.C, WANG K. S., HSIAO T.E., LIN I.C., WU H.J., WU Y.L., LIU P.H., CHANG S.H. Effects of UV irradiation on humic acid removal by ozonation, Fenton and $\mathrm{Fe}^{0}$ /air treatment: THMFP and biotoxicity evaluation. Journal of Hazardous Materials 195, 324, 2011.

32. OSKOEI V., DEHGHANI M.H., NAZMARA S., HEIBATI B., ASIF M., TYAGI I., AGARWAL S., GUPTA V.K. Removal of humic acid from aqueous solution using $\mathrm{UV} / \mathrm{ZnO}$ nano-photocatalysis and adsorption. Journal of Molecular Liquids 213, 374, 2016.

33. IQBAL M., ABBAS M., ARSHAD M., HUSSANIN T., KHAN A.U., MASOOD N., TAHIR M.A., HUSSAIN S.M., BOKHARI T.H., KHERA R.A. Gamma radiation treatment for reducing cytotoxicity and mutagenicity in industrial wastewater. Polish Journal of Environmental Studies, 24 (6), 2745, 2015.

34. IQBAL M., BHATTI I.A. Gamma radiation $/ \mathrm{H}_{2} \mathrm{O}_{2}$ treatment of a nonylphenol ethoxylates: Degradation, cytotoxicity, and mutagenicity evaluation. Journal of Hazardous Materials, 299, 351, 2015

35. IQBAL M., NISAR J., ADIL M., ABBAS M., RIAZ M., TAHIR M.A., YOUNUS M., SHAHID M. mutagenicity and cytotoxicity evaluation of photo-catalytically treated petroleum refinery wastewater using an array of bioassays. Chemosphere 168, 590, 2017.

36. RAJCA M., BODZEK M. Kinetics of fulvic and humic acids photodegradation in water solutions. Separation and Purification Technology 120, 35, 2013.

37. NAKATA K., FUJISHIMA A. $\mathrm{TiO}_{2}$ photocatalysis: design and applications. Journal of Photochemistry and Photobiology C: Photochemistry Reviews 13, 169, 2012.

38. ZHOU W., SUN F., PAN K., TIAN G., JIANG B., REN Z., TIAN C., FU H. Well-ordered large-pore mesoporous anatase $\mathrm{TiO}_{2}$ with remarkably high thermal stability and improved crystallinity: preparation, characterization, and photocatalytic performance. Adv. Funct. Mater. 21, 1922, 2011.

39. FENOLL J., FLORES P., HELLIN P., MARTINEZ C.M., NAVARRO S. 2012. Photodegradation of eight miscellaneous pesticides in drinking water after treatment with semiconductor materials under sunlight at pilot plant scale. Chem. Eng. J. 204-206, 54, 2012.

40. KANAKARAJU D., MOTTI C.A., GLASS B.D., OELGEMOLLER M. $\mathrm{TiO}_{2}$ photocatalysis of naproxen: effect of the water matrix, anions and diclofenac on degradation rates. Chemosphere 139, 579, 2015.

41. ZHANG L., XING Z., ZHANG H., LI Z., WU X., ZHANG X., ZHANG Y., ZHOU W. High thermostable ordered mesoporous $\mathrm{SiO}_{2}-\mathrm{TiO}_{2}$ coated circulating-bed biofilm reactor for unpredictable photocatalytic and biocatalytic performance. Appl. Catal. B Environ. 180, 521, 2016.

42. CHAO-YIN K., YA-HUI Y. Exploring the photodegradation

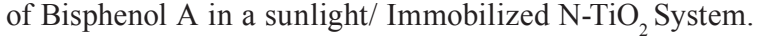
Polish Journal of Environmental Studies 23 (2), 379, 2014.

43. VALENCIA S., MARIN J.M., RESTREPO G., FRIMMEL F.H. Evaluations of the $\mathrm{TiO}_{2} /$ simulated solar UV degradations of XAD fractions of natural organic matter from a bog lake using size-exclusion chromatography. Water Res. 47 (14), 5130, 2013.

44. LAOUFI N.A., HOUT S., TASSALIT D., OUNNAR A., DJOUADI A., CHEKIR N., BENTAHAR F. Removal of a Persistent Pharmaceutical Micropollutant by $\mathrm{UV} / \mathrm{TiO}_{2}$ Process Using an Immobilized Titanium Dioxide Catalyst: Parametric Study. Chemical Engineering Transactions 32, 1951, 2013.

45. CZECH B. Effect of $\mathrm{H}_{2} \mathrm{O}_{2}$ addition on phenol removal from wastewater using $\mathrm{TiO}_{2} / \mathrm{Al}_{2} \mathrm{O}_{3}$ as photocatalyst. Polish Journal of Environmental Studies 18 (6), 989, 2009.

46. ZMUDZINSKI W. Removal of o-cresol from water by adsorption photocatalysis. Polish Journal of Environmental Studies 19 (6), 1353, 2010.

47. YAP P.S., LIM T.T., LIM M., SRINIVASAN M. Synthesis and characterization of nitrogen-doped $\mathrm{TiO}_{2} / \mathrm{AC}$ composite for the adsorption-photocatalytic degradation of aqueous bisphenol - A using solar light. Catalysis Today 151, 8, 2010.

48. KIM C., KIM J.T., KIM K.S., JEONG S., KIM H.Y., HAN Y.S. Immobilization of $\mathrm{TiO}_{2}$ on an ITO substrate to facilitate the photoelectrochemical degradation of an organic dye pollutant. Electrochimica Acta. 54, 5715, 2009.

49. BAEK M.H., JUNG W.C., YOON J.W., HONG J.S., LEE Y.S., SUH J.K. Preparation, characterization and photocatalytic activity evaluation of micro and mesoporous $\mathrm{TiO}_{2}$ /spherical activated carbon. Journal of Industrial and Engineering Chemistry 19, 469, 2013.

50. PORTJANSKAJA E., STEPANOVA K., KLAUSON D., PREIS S. The influence of titanium dioxide modifications on photocatalytic oxidation of lignin and humic acids. Catalysis Today. 144, 26, 2009.

51. WANG X., WU Z., WANG Y., WANG W., WANG X., BU Y., ZHAO J. Adsorption-photodegradation of humic acid in water by using $\mathrm{ZnO}$ coupled $\mathrm{TiO}_{2} /$ bamboo charcoal under visible light irradiation. Journal of Hazardous Materials 262, 16, 2013

52. XUE G., LIU H., CHEN Q., HILLS C., TYRER M., INNOCENT F. Synergy between surface adsorption and photocatalysis during degradation of humic acid on $\mathrm{TiO}_{2}$ /activated carbon composites. Journal of Hazardous Materials 186, 765, 2011.

53. MORI M., SUGITA T., MASE A., FUNATOGAWA T., KIKUCHI M., AIZAWA K., KATO S., SAITO Y., ITO T., ITABASHI H. Photodecomposition of humic acid and natural organic matter in swamp water using a $\mathrm{TiO}_{2}$-coated ceramic foam filter: Potential for the 
formation of disinfection byproducts. Chemosphere $\mathbf{9 0}$, 1359, 2013.

54. ZHANG X., JIANHONG A., LEE P., DELAI D., LECKIE J.O. $\mathrm{TiO}_{2}$ nanowire membrane for concurrent filtration and photocatalytic oxidation of humic acid in water. Journal of Membrane Science 313, 44, 2008.

55. DAELS N., RADOICIC M., RADETIC M., DE CLERCK K., VAN HULLE S.W.H. Electrospun nanofibre membranes functionalised with $\mathrm{TiO}_{2}$ nanoparticles: Evaluation of humic acid and bacterial removal from polluted water. Separation and Purification Technology 149, 488, 2015.

56. PATSIOS S.I., SARASIDIS V.C., KARABELAS A.J. A hybrid photocatalysis - ultrafiltration continuous process for humic acids degradation. Separation and Purification Technology 104, 333, 2013.

57. MA N., ZHANG Y., QUAN X, FAN X., ZHAO H. Performing a microfiltration integrated with photocatalysis using an $\mathrm{Ag}-\mathrm{TiO} \mathrm{O}_{2} / \mathrm{HAP} / \mathrm{Al}_{2} \mathrm{O}_{3}$ composite membrane for water treatment: Evaluating effectiveness for humic acid removal and anti-fouling properties. Water Research 44, 6104, 2010.

58. BIRBEN N.C., UYGUNER-DEMIREL C.S., KAVURMACI S.S., GURKAN Y.Y., TURKTEN N., CINAR Z., BEKBOLE M. Application of Fe-doped $\mathrm{TiO}_{2}$ specimens for the solar photocatalytic degradation of humic acid. Catalysis Today 281, 78, 2017.

59. LAZAU C., RATIU C., ORHA C., PODE R., MANEA F. Photocatalytic activity of undoped and Ag-doped $\mathrm{TiO}_{2}$-supported zeolite for humic acid degradation and mineralization. Materials Research Bulletin 46, 1916, 2011.

60. RASHID S.G., GONDAL M.A., HAMEED A., ASLAM M., DASTAGEER M.A., YAMANI Z.H., ANJUM D. H. Synthesis, characterization and visible light photocatalytic activity of $\mathrm{Cr}^{3+}, \mathrm{Ce}^{3+}$ and $\mathrm{N}$ co-doped $\mathrm{TiO}_{2}$ for the degradation of humic acid. RSC Adv. 5, 32323, 2015.

61. PINHEDO L., PELEGRINI R., BERTAZZOLI R., MOTHEO A.J. Photoelectrochemical degradation of humic acid on a $\left(\mathrm{TiO}_{2}\right)_{0.7}\left(\mathrm{RuO}_{2}\right)_{0.3}$ dimensionally stable anode. Applied Catalysis B: Environmental 57, 75, 2005.

62. SELCUK H., BEKBOLE M. Photocatalytic and photoelectrocatalytic humic acid removal and selectivity of $\mathrm{TiO}_{2}$ coated photoanode. Chemosphere 73, 854, 2008.

63. PAOLA A.D., GARCIA-LOPEZ E., MARCI G., PALMISANO L. A survey of photocatalytic materials for environmental remediation. Journal of Hazardous Materials 211-212, 3, 2012.

64. FRENCH R.A., JACOBSON A.R., KIM B., ISLEY S.L., PENN R.L., BAVEYE P.C. Influence of ionic strength, $\mathrm{pH}$, and cation valence on aggregation kinetics of titanium dioxide nanoparticles. Environ Sci Technol. 43, 1354, 2009.

65. MOZIA S. Photocatalytic membrane reactors (PMRs) in water and wastewater treatment. A review. Separation and Purification Technology 73, 71, 2010.

66. IBHADON A., FITZPATRICK P. Heterogeneous Photocatalysis: Recent Advances and Applications. Catalysts 3, 189, 2013.

67. LIU J., BAI H., WANG Y., LIU Z., ZHANG X., SUN D.D. Self-assembling $\mathrm{TiO}_{2}$ nanorods on large graphene oxide sheets at a two-phase interface and their antirecombination in photocatalytic applications. Adv. Funct. Mater. 20, 4175, 2010.

68. XU C., CUI A., XU Y., FU X. Graphene oxide-TiO composite filtration membranes and their potential application for water purification. Carbon 62, 465, 2013.
69. SELCUK H., BEKBOLE M. Photocatalytic and photoelectrocatalytic humic acid removal and selectivity of $\mathrm{TiO}_{2}$ coated photoanode. Chemosphere 73, 854, 2008.

70. LI A., ZHAO X., LIU H., QU J. Characteristic transformation of humic acid during photoelectrocatalysis process and its subsequent disinfection byproduct formation potential. Water Research 45, 6131, 2011.

71. PANSAMMUT G., CHARINPANITKUL T., SURIYAWONG A. Removal of Humic Acid by Photocatalytic Process: Effect of Light Intensity. Engineering Journal 17 (3), 25, 2013.

72. CHONG M.N., JIN B., CHOW C.W.K., SAINT C. Recent developments in photocatalytic water treatment technology: A review. Water research 44, 2997, 2010.

73. UMAR M., AZIZ H.A. Photocatalytic Degradation of Organic Pollutants in Water, in: Organic Pollutants, Monitoring, Risk and Treatment, (Rashed, M. N., (Eds.)), InTechOpen Publisher, 195, 2013 http://dx.doi. org/10.5772/53690

74. GAYA U.I., ABDULLAH A.H. Heterogeneous photocatalytic degradation of organic contaminants over titanium dioxide: A review of fundamentals, progress and problems. Journal of Photochemistry and Photobiology C: Photochemistry Reviews 9, 1, 2008.

75. UYGUNER C.S., BEKBOLE M. A comparative study on the photocatalytic degradation of humic substances of various origins. Desalination 176, 167, 2005.

76. BIRBEN C., BEKBOLE M. Key role of common anions on the photocatalytic degradation profiles of the molecular size fractions of humic acids. Catalysis Today 209, 122, 2013.

77. LUTTRELL T., HALPEGAMAGE S., TAO J., KRAMER A., SUTTER E., BATZILL M. Why is anatase a better photocatalyst $\mathrm{TiO}_{2}$ films. Sci. Rep. 4, 4043, 1, 2014.

78. HAQUE M.M., BAHNEMANN D., MUNEER M. Photocatalytic Degradation of Organic Pollutants: Mechanisms and Kinetics, in: Organic Pollutants Ten Years after the Stockholm Convention - Environmental and Analytical Update, 293, 2012.

79. ZHANG X., PAN J.H., DU A.J., FU W., SUN D.D., LECKIE J.O. Combination of one-dimensional $\mathrm{TiO}_{2}$ nanowire photocatalytic oxidation with microfiltration for water treatment. Water Research 43, 1179, 2009.

80. PAZ Y. Preferential photodegradation - Why and how? C. R. Chimie. 9, 774, 2006

81. PALMER F.L., EGGINS B.R., COLEMAN H.M. The effect of operational parameters on the photocatalytic degradation of humic acid. Journal of Photochemistry and Photobiology A: Chemistry 148, 137, 2002.

82. KONSTANTINOU I.K., ALBANIS T.A. $\mathrm{TiO}_{2}$ - assisted photocatalytic degradation of azo dyes in aqueous solution: kinetic and mechanistic investigations - A review. Applied Catalysis B: Environmental 49, 1, 2004.

83. LIU S., LIM M., FABRIS R., CHOW C., CHIANG K., DRIKAS M., AMAL R. Removal of humic acid using $\mathrm{TiO}_{2}$ photocatalytic process - Fractionation and molecular weight characterisation studies. Chemosphere 72, 263, 2008.

84. WANG P.F, QI N., AO Y.H., HOU J., WANG C., QIAN J. Effect of UV irradiation on the aggregation of $\mathrm{TiO}_{2}$ in an aquatic environment: Influence of humic acid and $\mathrm{pH}$. Environmental Pollution 212, 178, 2016.

85. DZIEDZIC J., WODKA D., NOWAK P., WARSZYNSKI P., SIMON C., KUMAKIRI I. Photocatalytic degradation of the humic species as a method of their removal from water - comparison of UV and artificial sunlight irradiation. 
Physicochemical Problems of Mineral Processing 45, 15, 2010.

86. REHMAN S., ULLAH R., BUTT A.M., GOHAR N.D. Strategies of making $\mathrm{TiO}_{2}$ and $\mathrm{ZnO}$ visible light active. Journal of Hazardous Materials 170, 560, 2009.

87. CHONG M.N., LEI S., JIN B., SAINT C., CHOW C.W.K. Optimisation of an annular photoreactor process for degradation of Congo Red using a newly synthesized titaniaim pregnated kaolinite nano-photocatalyst. Separation and Purification Technology 67, 355, 2009.

88. CHONG M.N., JIN B., ZHU H.Y., CHOW C.W.K., SAINT C. Application of $\mathrm{H}$-titanate nanofibers for degradation of
Congo Red in an annular slurry photoreactor. Chemical Engineering Journal 150, 49, 2009.

89. YIGIT Z., INAN H. A study of the photocatalytic oxidation of humic acid on anatase and mixed-phase anatase - rutile $\mathrm{TiO}_{2}$ nanoparticles. Water Air Soil Pollut: Focus 9, 237, 2009.

90. ERHAYEM M., SOHN M. Effect of humic acid source on humic acid adsorption onto titanium dioxide nanoparticles. Science of the Total Environment 471, 92, 2014.

91. LI X.Z., FAN C.M., SUN Y.P. Enhancement of photocatalytic oxidation of humic acid in $\mathrm{TiO}_{2}$ suspensions by increasing cation strength. Chemosphere $48,453,2002$. 